\title{
Covid-19 Salgınında Türkçe ve İngilizce Ünlülerin Damlacık Yayılımlarına Dair Fonolinguistik Bir Karşılaştırma
}

\author{
Ensar KILIÇ ${ }^{1}$
}

\begin{abstract}
Özet: SARS-CoV-2 virüsünün (şiddetli akut solunum yolu sendromu koronavirüsü 2) damlacık yoluyla bulaşması sonucunda meydana gelen 2019 Covid-19 küresel salgını, konuşma seslerinin bu virüsün yayılmasında ne denli etkili olduğunu tartışmaya açmıştır. Bu konuda özellikle İngilizcedeki konuşma sesleri üzerine çalışmalar yapılmış olsa da Türkçe konuşmanın damlacıkların yayılımına etkisi hususunda herhangi bir bilimsel yayın yoktur. İşte bu makalede Türkçenin hece ve fonolojik sisteminin en önemli sesletim parçalarından olan ünlüler, İngilizcedeki ünlülerle daha önce yapılmış bilimsel çalışmalardan elde edilen veriler kullanılarak F1 ve F2 frekans değerleri bakımından fonolinguistik bir yaklaşımla karşılaştırılmıştır. Ayrıca ana dili Türkçe olmakla birlikte Amerikan veya Britanya İngilizcesini sonradan öğrenip yabancı dil olarak konuşan kişilerin ünlüleri boğumlarken kullandığg frekans değerleri, Türkçedeki ve İngilizcedeki ünlü fonemlere ait değerlerle mukayese edilmiştir. Aynı zamanda ünsüzlerin damlacık yayılımı konusundaki etkileri, ünlü seslerle olan ses birleşimlerine dair münasebetleri bağlamında tartışılmış; günlük hayatta sıkça yüksek sesle telaffuz edilen temel seslenme ve esenlik sözlerinin fonolojik varllğg ve bu kelimelerin damlacık yayma potansiyelleri -ses sıklık listelerinin de yardımıyla- değerlendirilmiştir. Bu karşılaştırma ve değerlendirmeler neticesinde ünlülerin birçoğunun boğumlanması esnasında Türkçenin İngilizceden oransal olarak daha düşük frekans değerleri ürettiği sonucuna varılmıştır. Ancak Türkçedeki "merhaba, anne, baba" gibi temel seslenme ve esenlik sözlerinin yüksek oranda damlacık yayılımı oluşturan fonemlerden oluştuğu anlaşılmıştır. Yine damlacık yayılımı yüksek birçok sesin Türkçede en sık kullanılan fonemlerden olduğu ve bu seslerden gündelik konuşma sırasında sıkça faydalanıldığı görülmüştür. Bu nedenle ünlülerin frekans değerleri bakımından Türkçe, birçok kez İngilizceden daha düşük değerlere ihtiyaç duysa da bu durum Türkçenin İngilizceden daha az damlacık yayan bir dil olduğu yönünde kesin bir kanıt sağlamamaktadır.
\end{abstract}

Anahtar Kelimeler: SARS-CoV-2, Covid-19 ve Türkçe, damlacık yoluyla bulaşma, konuşma sırasında bulaşma.

\section{A Phonolinguistic Comparison of Droplet Spreads of Turkish and English Vowels in the Covid-19 Outbreak}

\begin{abstract}
The Covid-19 pandemic, which expands with the transmission of the SARS-CoV-2 virus (severe acute respiratory syndrome coronavirus 2) through droplets, has opened up the discussion of the effects of speech sounds on the pandemic. Although there are many studies on English in this regard, there is no Turkishbased study yet. In this article, vocals, one of the most important parts of the phonological system of Turkish, were compared with the vowels in English using the data obtained from previous scientific studies in terms of F1 and F2 frequencies. The vowel frequencies in English and Turkish have been checked against with the frequencies they use when speaking English of people who grows up speaking Turkish and then learns English. Also, the effects of consonants on droplet propagation are discussed in the context of consonants' relationships with vowels. The phonological existence of the basic calling and meet words that are frequently used in daily life were evaluated in terms of their droplet spread potential. As a result of the comparisons made, it was concluded relatively that Turkish produced lower frequency values than English during the articulation of vowels. In Turkish, it was determined that the sounds in some of the most common daily words like merhaba "hello, hi", anne "mother", baba "father" spread high droplets. Also, many of the phonemes commonly used in Turkish have a high droplet spread. In summary, the fact that Turkish vowels are articulated with lower frequencies than English does not mean that Turkish vowels emit less droplets.
\end{abstract}

Keywords: SARS-CoV-2, Covid-19 and Turkish, droplet transmission, transmission during speech.

\footnotetext{
${ }^{1}$ Orcid ID: https://orcid.org/0000-0003-2294-4443, Doktora, Anadolu Üniversitesi Sosyal Bilimler Fakültesi, Türk Dili ve Edebiyatı Anabilim Dalı, Eskişehir-Türkiye, ensarkilic@ @otmail.com.tr
} 


\section{Summary}

As with many other respiratory diseases, SARS-CoV-2 is transmitted by micro-droplets produced in the airway from an infected person; these droplets are expelled from the body during coughing, sneezing and normal speech. Studies are using laser lights on the subject revealed that intense droplet spread occurred during loud speech and it took 8 to 14 minutes to disappear in closed environments. Indeed, research in the context of the effect of sounds on disease propagation has shown that the droplet propagation capacity of each voice is not equal during speech. This ratio is also related to the density of the particles scattered around the environment, the way the person making the sound uses the sound and the speed of the articulation of the sound. The Covid19 pandemic, which expands with the transmission of the SARS-CoV-2 virus through droplets, has opened up the discussion of the effects of speech sounds on the pandemic. Although there are many studies on English in this regard, there is no Turkish-based study yet. However, some reports in the Turkish press, have made claims that Turkish emits fewer droplets than many other languages, including English. In this article, vocals, one of the most important parts of the syllable and phonological system of Turkish, were compared with the vowels in English using the data obtained from previous scientific studies in terms of F1 and F2 frequencies. The vowel frequencies in English and Turkish have been checked against with the frequencies they use when speaking English of people who grows up speaking Turkish and then learns English. Also, the effects of consonants on droplet propagation are discussed in the context of consonants' relationships with vowels. The phonological existence of the basic calling and meet words that are frequently used in daily life were evaluated in terms of their droplet spread potential. Comparing the droplet spread of vowels during Turkish speech with English, the following conclusions were reached: 1. In Turkish speeches, vowels produce lower frequency values compared to American English. The sounds of /a/, /i/ and /u/ at the ends of the triangle forming the maximal void space field in the F1 and F2 formant plane are the "main vowels" in almost all languages. The fact that these vowels have the highest droplet spread is common to English and Turkish. 2. The vowels used by individuals who speak American or British English with a Turkish accent have slightly higher frequencies than the vowels they use when speaking their mother tongue. 3. Turkish, which produces lower frequencies than English in terms of celebrities, needs less pressure than English to discharge the air to the outside environment. Although the effect of this situation on the number of emitted droplets is hypothetical, it is understood that English vowels have at least the ability to spread the droplets over a larger area due to the power of the frequency. However, it is unclear whether this effect would result in a significant difference to the extent of the outbreak. Because $66 \%$ of the sounds used during Turkish speaking are phonemes with high droplet spread. In addition, there are voices that show intense droplet dispersion during loud artikulation in the content of the words loudly used, such as merhaba "hello", anne "mother", baba "father", gel "come on", git "go". 4. The vowels are the most determinant parts of the acoustic structure in a language and are the feet of the general resonance system of the languages. In this respect, consonants gain importance in the context of their interaction with vowels in resonance based comparison. In short, in evaluations about consonants, findings obtained with modern imaging systems come to the fore rather than formant analysis. Compared to English and Turkish consonants, the general consonant existence is similar except for the voices specific to both languages. Research with statistical methods in this regard, contrary to popular belief, revealed that voiced consonants spread more droplets than voiceless consonants. Again, in these studies, it was understood that explosive consonants had more intense droplet release than fricative consonants. In addition, nasal consonants, which show close characteristics with vowels, have been found to increase the risk of infection. 5. It has been evaluated that Turkish has some advantages in terms of droplet spread compared to English, but because of these advantages, Turkish cannot be interpreted as an ideal language in terms of not expanding the epidemic. There are many different factors for droplet propagation to occur while speaking a language. The fact that one tongue is less stressed than the other or evacuates sounds with less pressure will not alone determine the ability of the virus to spread. In this regard, other factors such as the high volume of droplet density in the vocabulary of languages, the extent of the loud speaking habit in humans and whether the exhaled air comes directly from the lung are also effective.

Keywords: SARS-CoV-2, Covid-19 and Turkish, droplet transmission, transmission during speech. 


\section{Giriş}

Pandemi dönemlerinde, virüs ve bakterilerin bireyleri nasıl enfekte ettiği ve bu enfeksiyonların toplumdaki yayılımının nasıl önleneceği konusunda mikrobiyoloji, patogenez, epidemiyoloji, tıp, mühendislik ve fizik gibi alanlar farklı bakış açılarıyla birçok araştırmaya imza atmıştır (Morawska, 2005: 9-11). Ancak mevzu ağız yoluyla yayılan damlacıklar olduğunda, salgınların fonolojik bir yönünün de bulunduğu unutulmamalıdır. Nitekim dilsel işlemlerin konuşma sesleri vasıtasıyla gerçekleşmesi akciğerler, ses telleri ve bir dizi rezonans odası (örneğin ağız ve burun boşlukları) arasındaki karmaşık bir etkileşimi içermektedir (Wagner vd., 2017: 3457). Bu ilişki ağ1, konuşmayı sağlayan organlarda bulunan mikroorganizmaların fonemik boğumlanmalar neticesinde solunum yoluyla dışarıya atılması durumunu ortaya çıkarmaktadır.

Solunum yoluyla bulaşan birçok virüste olduğu gibi SARS-CoV-2 de enfekte olmuş bir kişiden hava yolunda üretilen mikro damlacıklar ile bulaşmakta; bu damlacıklar öksürük, hapşırma ve normal konuşma sırasında vücuttan dışarı atılmaktadır (Kowalik vd., 2020: 100). Yani SARS-CoV-2'nin de tıpkı diğer koronavirüsler gibi ortamdaki damlacıklardan bulaşma potansiyeli çok yüksektir (bk. Wolf vd., 2005: 203-204; Kowalik vd., 2020: 100).

\section{Konuşmanın SARS-CoV-2'nin Bulaşmasındaki Etkisi}

Konuşma seslerinin solunum yoluyla bulaşan hastalıklara etkisi muhtelif çalışmalara konu olmakla birlikte bu hususta Türkçe üzerine yapılmış herhangi bir araştırma yoktur. Bununla birlikte Covid-19 pandemisi esnasında bazı enfeksiyon uzmanları Türkçenin İngilizce, İspanyolca, İtalyanca ve Rusça gibi dillere nazaran daha az damlacık yayan bir dil olduğunu iddia etmiştir. ${ }^{2}$ Damlacık yayılımına dair lazer 1şıkları kullanılarak yapılan çalışmalar, yüksek sesli konuşma esnasında yoğun bir damlacık yayılımının gerçekleştiğini ve kapalı ortamlarda bu damlacıkların kaybolmasının 8 ile 14 dakika arasındaki bir zamanda gerçekleştiğini ortaya koymuştur (Stadnytskyi vd., 2020: 1). Ayrıca konuşma esnasında ortama yayılan bu damlacıkların çapının hastalığın bulaşması için yeterli boyutta olabileceği ve damlacık yayma yoğunluğunun kişiden kişiye değiştiği bilinmektedir (Stadnytskyi vd., 2020: 1-3). Tam da bu noktada seslerin boğumlanma sonrasında ağızdan tahliye ettikleri damlacıkların boyutu ve yoğunluğu önem kazanmaktadır. Çünkü ağız yoluyla yayılan damlacıkların boyutu, damlacıkların içindeki mikroorganizmaların hayatta kalmasını belirleyen anahtar faktördür (Morawska, 2005: 9-11).

Konu ile ilgili mevzulardan bir diğeri, dillerin salgın hastalıkların yayılımındaki oransal etkisidir. Bu konuda ilk olarak 2003'te yaşanan SARS salgını esnasında ortaya çıkan bazı veriler, böyle bir

\footnotetext{
227 Mart 2020 tarihinde Kanal D Ana Haber Bülteni’nde Enfeksiyon Hastalıkları Derneği Başkanı Prof. Dr. Mehmet Ceyhan, Türkçenin damlacık yayma yoğunluğunun İngilizce, Rusça, İtalyanca ve İspanyolca gibi dillere göre daha az olduğunu, dolayısıyla Türkçe konuşma esnasında virüsün yayılma olasılığının düştüğünü ifade etmiştir.
} 
durumun söz konu olabileceği düşüncesini uyandırmıştır. Nitekim Inouye, SARS salgını esnasında ABD ve Çin'de vaka sayısının artmasına ve bu ülkelerde çok sayıda Japon turist olmasına rağmen 2003 Haziran'ında hiçbir Japon'da bu hastalığa rastlanmamasının tesadüf olmayacağını düşünmektedir. Ona göre Çince ve İngilizce önemli oranda patlayıcı ünsüze sahiptir ve özellikle Çince bir vurgulama dilidir. $\mathrm{Bu}$ dilde $/ \mathrm{p}, \mathrm{t}, \mathrm{k}, \mathrm{k}$, ç, s/ sesleri ötümsüzdür ve ünlülerin başına geldiklerinde güçlü bir nefesle sesletilir. Japoncaya kıyasla İngilizcede de bu ötümsüz seslerin boğumlanması esnasında çok daha şiddetli bir hava boşaltımı gerçekleştirilir. Bu durumda Japonca konuşurlarının damlacık yayılımı Çinli ve Amerikalılara göre çok daha azdır (Inouye, 2003: 170). Inouye'nin bu içgörüsünde her ne kadar ötümsüz seslerin virüsü yayma konusundaki etkisi vurgulansa da laboratuvar çalışmaları ötümlü seslerin ötümsüzlerden daha fazla damlacık yayılımına neden olabileceğini göstermiştir (Asadi, 2020: 11-12).

\section{Seslerin Hastalık Bulaştırma Konusundaki Farklılıkları}

Seslerin hastalık yayılımına etkisi bağlamında yapılan araştırmalar göstermiştir ki her sesin konuşma esnasında damlacık yayma kapasitesi eşit değildir. Bu oran, çevreye yayılan parçacıkların yoğunluğu, sesletimi yapan bireyin sesi kullanma biçimi ve sesin boğumlanma hızıyla da ilişkilidir (Asadi vd., 2020: 11). Nitekim bir sesin damlacık yayılımının yoğunluğunu pek çok faktör belirlemektedir. Bir başka deyişle damlacık yayılımının yoğunluğu hususunda; sesin ne kadar havayla, ne kadar sürede, ne tür bir titreşim aralığında tahliye edildiği; kısacası dalga formu önem kazanmaktadır.

\section{Türkçe ve İngilizce Ünlülerin Damlacık Yayılımına Etkisi}

Ünsüzlere oranla bir kelimedeki ünlü içeriği arttıkça damlacık yayılım oranını da doğru orantılı bir biçimde artar (Asadi vd., 2020: 11). Yani bir dildeki damlacık yayılım oranlarını belirleyen en temel sesler ünlülerdir.

Asadi ve arkadaşları tarafından 56 kişi üzerinde yapılan bir araştırmada damlacık yayılımı en yüksek olan ünlünün /i/ olduğu tespit edilmiştir (2020: 8). Çalışmaya göre /a/ ve /u/ fonemleri de önemli oranda damlacık yayılımına neden olmaktadır. Araştırmaya göre bu durumun sebebi; /a/, /i/ ve /u/ seslerinin boğumlanması esnasında diğer seslere oranla daha fazla enerji harcanıyor olmasıdır (2020: 11). Burada konuşma için ana enerji kaynağı olan akciğerden gelen basıncın bu seslerde daha yüksek olması da etkilidir (2020: 11).

Türkçedeki ünlüler, ünsüzlere oranla ağız kanalının daha açık bir biçimde kullanılmasıyla teşekkül eder. Yani Türkçedeki ünlüler, ses yolunda herhangi bir takıntı ya da engelle karşılaşmadan boğumlanan seslerdir (Aksan, 2015: 24; Ergin, 2008: 34-35). Bu seslerin belirli nazalans (genizsillik) değerleri bulunmakla birlikte, genel olarak Türkçedeki ünlüler ağız ünlüleri kategorisinde değerlendirilen “berrak ünlü”lerdir (Aksan, 2015: 24; Saraç, 2010: 40-69). İngilizce odaklı 
çalışmalarda /a/, /i/ ve /u/ seslerinin en yüksek boğumlanma gücüne sahip ünlüler olduğu yönündeki bulgular Türkçe için de geçerlidir. F1 ve F2 formant düzlemindeki maksimal sesli boşluk alanını oluşturan üçgenin uçlarında bulunan /a/, /i/ ve /u/ sesleri neredeyse tüm dillerde bulunan "temel ünlüler"dir (Boë vd., 2004: 409; Boë vd., 2007: 565; Aksan, 2015: 27). ${ }^{3}$ Nitekim Türkçede /i/ ağzın en önünde, /a/ ağzın en açık olduğu durumda, /u/ ise en arkada söylenmesi nedeniyle bu seslerin teşekkülü esnasında havanın ciğerden doğrudan tahliyesi kolaylaşmaktadır (bk. Aksan, 2015: 27).

İngilizce odaklı çalışmalardaki ünlü envanterine dair bazı bulguların Türkçe için de anlam ifade ediyor olması, bu çalışmaların Türkçe için tam bir uyumluluk göstereceği sonucunu doğurmamaktadır. Nitekim farklı diller bir yana, İngilizceyi konuşan yabancı kökenli kişilerin bile İngilizceye özgü ünlüleri farklı niteliklerde telaffuz ettiği bilinmektedir. Wang ve Heuven tarafından yapılan bir çalışmada, İngilizceyi yabancı dil olarak konuşan Çin kökenlilerin \%75, Hollanda kökenlilerin ise $\% 85$ oranında bu dildeki ünlülerin fonolojik yapısıyla tutarlı sesletimler gerçekleştirdiğini saptanmıştır (2006: 245-247). Yine formant değerlerindeki bu farklar aynı dilin farklı ağızlarında bile ciddi frekans değişimleri meydana getirebilmektedir. Örneğin Türkiye’nin farklı bölgelerinde yapılan bir formant analizinde her bölgede muhtelif değerlerin ortaya çıtı̆̆ görülmüştür (Çiyiltepe vd., 2009: 3). Bu durum frekans değerlerinin dilin akustiği hakkında fikir verdiği ancak aynı dil içinde bile sabit ölçülemeyen belirli bir sayısal genişliği barındırdığını ima etmektedir. Bu açıdan frekans karşılaştırmalarında küçük farklardan ziyade genel eğilime ve önemli derecedeki farklara odaklanmak gerekmektedir.

İngilizcedeki ve Türkçedeki ünlülerin temel akustik farklarını ortaya koymak için en elverişli yöntem F1 ve F2 formantlarının karşılaştırılmasıdır. Çünkü ünlüler genellikle akustik değerlendirmelerde F1 ve F2 formant değerleriyle parametrelendirilmektedir (Artuner, 1994: 41).

Türkçedeki ve İngilizcedeki (Amerikan) ünlüler bağımsız frekans değerleri üzerinden F1 formantı açısından karşılaştırıldığında, İngilizce ünlülerin Türkçeden daha yüksek frekans değerlerinde boğumlandığ1 görülmektedir. Nitekim erkek ve kadın konuşurların ortalama F1 ve F2 frekans değerleri dikkate alındığında, Türkçede söz sonundaki /u/ foneminin bir alofonu olan [ ] (Göksel \& Kerslake, 2004: 10) dışında, Türkçenin İngilizceden daha yüksek bir F1 ya da F2 frekansında boğumladığı herhangi bir ünlü yoktur (Ng vd., 2008: 406):

Şekil 1: Türkçe ve Amerikan İngilizcesindeki Ünlülerin F1 Frekansı Açısından Karşılaştırılması (Ng vd., 2008: 406)

\footnotetext{
${ }^{3}$ Ses yolunda oluşan enerji yoğunlukları formant olarak adlandırılır (Davutoğlu, 2010, s. 102). "F1 değerleri dilin yüksekliği, F2 değerleri ise dilin ön-arka konumlanışı ve dudak yuvarlaklığı ile ilgili fikir vermektedir (Malkoç, 2009, 76)."

${ }^{4}$ (a) ile etiketlenmiş tablo erkek, (b) ile etiketlenmiş tablo kadın konuşurların frekans değerlerini temsil etmektedir.
} 


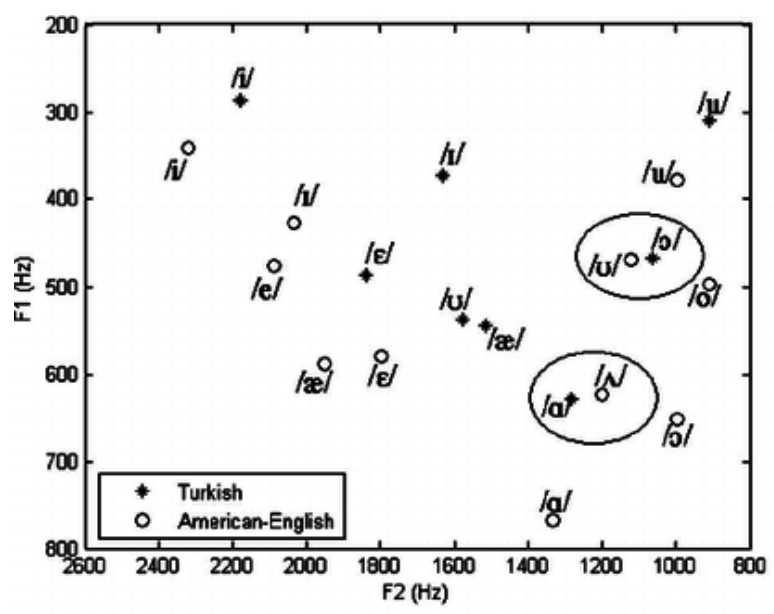

(a)

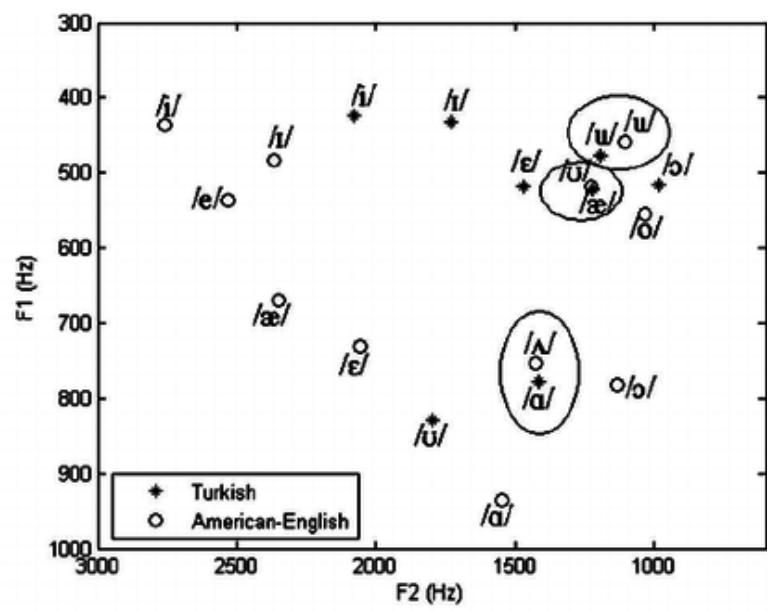

(b)

Türk aksanlı farklı dil konuşurları üzerinde yapılan çalışmalar da Türkçenin ünlü frekans değerleri hususunda diğer dillerle kıyaslanmasında önemli veriler sunmaktadır. Çünkü yabancı aksanlar, ana dilin etkisi altında bulunan ve bu etki altında hedef dilde boğumlanan alofonik türevlerdir (Sadaka \& $\mathrm{Ng}$, 2008: 3423). Nitekim Ng ve arkadaşları tarafından yapılan çalışma Türkçe aksanlı ünlülerin boğumlanması esnasında özellikle F2 formantında İngilizceden (Amerikan) daha düşük frekansların kullanıldığını, bazı F1 formantlarında ise çok sınırlı bir artışın bulunduğunu göstermektedir (2008: 408-409):

Tablo 1: Türkçe Aksanlı Amerikan İngilizcesi Konuşan Kişilere ile Ana Dili Amerikan İngilizcesi Olanlara Ait Ünlü Frekanslarının Karşılaştırılması

\begin{tabular}{|c|c|c|c|c|c|c|}
\hline 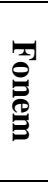 & 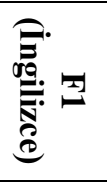 & 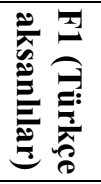 & 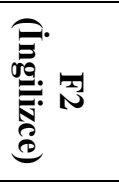 & 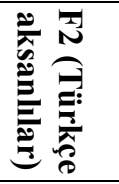 & 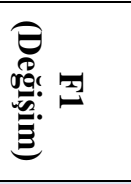 & 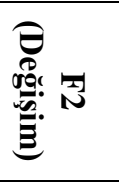 \\
\hline i & 310,5 & 349,5 & 2630 & 2297,5 & Artış & Azalma \\
\hline $\mathbf{I}$ & 462,5 & 479 & 2071,5 & 2026,5 & Artış & Azalma \\
\hline $\mathbf{e}$ & 424 & 552,5 & 2149 & 1999,5 & Artış & Azalma \\
\hline $\mathfrak{x}$ & 893 & 723 & 1850 & 1606,5 & Azalma & Azalma \\
\hline $\boldsymbol{\Lambda}$ & 688,5 & 714 & 1585 & 1250,5 & Artış & Azalma \\
\hline $\mathbf{a}$ & 870 & 709,5 & 1407,5 & 1197 & Azalma & Azalma \\
\hline$\varepsilon$ & 661 & 630 & 1963 & 1740,5 & Azalma & Azalma \\
\hline $\boldsymbol{o}$ & 819 & 641,5 & 1343 & 1173,5 & Azalma & Azalma \\
\hline $\boldsymbol{\sigma}$ & 482 & 476 & 1464,5 & 1205 & Azalma & Azalma \\
\hline $\mathbf{u}$ & 353 & 444 & 1169 & 1126,5 & Artış & Azalma \\
\hline $\mathbf{0}$ & 459,5 & 575,5 & 1139 & 1141,5 & Artış & Artış \\
\hline
\end{tabular}

$\mathrm{Bu}$ tablo en çok damlacık yayan /a, i, u/ sesleri açısından yorumlandiğında, Türkçenin F1 frekanslarında /i, u/ ünlüleri açısından İngilizceye göre daha yükssek frekans değerlerine sahip olduğu görülmektedir. Bununla birlikte /i/ ünlüsündeki frekans farkı oldukça azdır. 
Kıbrıs Türk aksanıyla İngilizce (Britanya) konuşan bireyleri konu alan bir diğer çalışmada ise F1 ve F2 frekansları açısından şu karşılaştırmalı verilere ulaşılmıştır (bk. Hunter \& Yarkiner, 2014: 453457):

Tablo 2: Kıbrıs Türkçesi Aksanlı Britanya İngilizcesi Konuşan Kişiler ile Ana Dili Amerikan İngilizcesi Olanlara Ait Ünlü Frekanslarının Karşılaştırılması

\begin{tabular}{|c|c|c|c|c|c|c|c|}
\hline 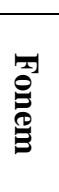 & 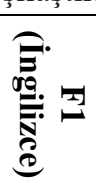 & 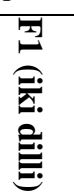 & 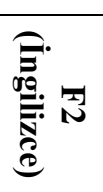 & 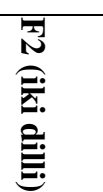 & 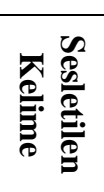 & 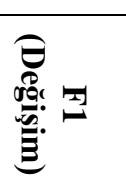 & 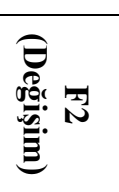 \\
\hline i: & 296 & 290 & 2241 & 2770 & bread & Azalma & Artış \\
\hline I & 396 & 320 & 1839 & 1445 & bid & Azalma & Azalma \\
\hline e & 532 & 665 & 1656 & 1585 & bed & Artış & Azalma \\
\hline $\mathfrak{x}$ & 667 & 650 & 1565 & 1575 & bad & Azalma & Artış \\
\hline$\Lambda$ & 661 & 605 & 1296 & 925 & bud & Azalma & Azalma \\
\hline a: & 680 & 500 & 1193 & 1800 & bard & Azalma & Artış \\
\hline D & 643 & 395 & 1019 & 865 & bod & Azalma & Azalma \\
\hline o: & 480 & 385 & 857 & 870 & bawd & Azalma & Artış \\
\hline $\boldsymbol{U}$ & 395 & 360 & 1408 & 1270 & good & Azalma & Azalma \\
\hline $\mathbf{u}:$ & 386 & 345 & 1587 & 1330 & booed & Azalma & Azalma \\
\hline 3: & 519 & 820 & 1408 & 1375 & bird & Artış & Azalma \\
\hline
\end{tabular}

Bu tabloya bakıldığında Türkiye Türkçesi merkezli değerlendirmeye göre Kıbrıs Türkçesinin F1 frekansları açısından İngilizceye (Britanya) göre daha düşük değerlerde parametrelendiği, F2 frekansları açısından ise Türkiye Türkçesi-İngilizce (Amerikan) karşılaştırmasına kıyasla Kıbrıs Türkçesinin İngilizce (Britanya) ile karşılaştırmasında, Kıbrıs Türkçesindeki ünlülerin Türkiye Türkçesindekilere göre bir miktar daha yüksek değerlerde boğumlandığı görülmektedir.

Tüm bu veriler dikkate alındığında,

i. İ́ki dilin bağımsız sesletimi parametresine göre Türkçedeki ünlülerin ortalama frekansının daha düşük değerlere sahip olduğu,

ii. İngilizceyi ${ }^{5}$ yabancı dil olarak konuşan Türklerin İngilizce sesleri boğumlaması esnasında ortalama frekans değerlerinin ana dili İngilizce olanlara göre bir miktar azalış gösterdiği,

iii. Türkçe aksanlı olarak İngilizce konuşulduğunda, Türkçe kelimelerin sesletimine kıyasla benzer ünlüler için bir miktar daha yüksek frekansların tercih edildiği görülmektedir.

\footnotetext{
${ }^{5}$ Amerikan veya Britanya İngilizcesi fark etmeksizin
} 


\section{1. Ünsüzlerin ve Sıklıkla Yüksek Sesle Üretilen Kelimelerin Ünlülerin Boğumlanmasına ve Damlacık Yayılımına Etkisi}

Ünlüler bir dildeki akustik yapının en belirleyici parçaları olup dillere özgü genel rezonans sisteminin sacayaklarıdır. Bu açıdan ünsüzler rezonansa dayalı incelemelerde ünlülerle oluşturdukları etkileşim bağlamında önem kazanmaktadır (Korkmaz \& Boyac1, 2018b: 1). Bu yönüyle ünsüzler için formant analizi yapmak "suyu arıtmaya" benzetilmektedir. Bunun sebebi, ünsüzlerin boğumlanması esnasında oluşan ağız yolu daralmalarının ses tellerindeki formantları bir ya da daha fazla frekansta ortadan kaldırmasıdır (Korkmaz \& Boyacı, 2018: 38). Kısacası ünsüzlerle ilgili değerlendirmelerde, formant analizlerinden çok modern görüntüleme sistemleriyle elde edilen bulgular ön plana çıkmaktadır. İngilizce ve Türkçe ünsüzler karşılaştırıldığında, her iki dile özgü sesler dışında genel olarak ünsüz varlığının benzer olduğu; dillere özgü ünsüzlerin yerine konuşma esnasında benzer ünsüzlerin ikame edildiği görülmektedir (Varol, 2012: 21).

Ünlüler dışındaki fonemlerin damlacık yayılımına etkisi, benzer boğumlanma şekillerine sahip olmalarından çok ne kadar basınçla, hangi boğumlanma merkezinden ve hangi ünlüyle sesletildikleriyle ilgilidir (Asadi vd., 2020: 11-12). Türkçedeki /p, b, f, v, s, ş, ç, z, k, g, t, d/ sesleri boğumlanma aşamasında havayı dışarı yüksek bir basınçla iten ünsüzlerdir (Saraç, 2010: 38). Yüksek basınçla boğumlanan ünsüzlerin bulaştırma riski hususunda havanın ciğerden çıkış şekli etkilidir. ${ }^{6} \mathrm{Bu}$ konuda istatiksel metotlarla yapılan araştırmalar, genel anlamda -yaygın inanışın aksine- ötümlü ünsüzlerin ötümsüzlerden daha fazla damlacık yayabildiğini ortaya koymuştur. Yine bu çalışmalarda patlayıcıların sürtünmeli ünsüzlerden daha yoğun damlacık salınımına sahip olduğu anlaşılmıştır. Ayrıca, ötümlü patlayıcılar olan /d, b, g/ ünsüzlerini içeren iki tekrarlı heceye sahip kelimelerin ötümsüz sürtünmelilerden (/f, h, s, ş/), ötümsüz bir patlayıcı olan /t/'nin (tata) /ş/'den (şaşa), ötümlü burun ünsüzü olan /m/'nin ise (mama) ötümsüz sürtünmeli /s/ ve /ş/'den daha fazla damlacık yaydığ1 saptanmıştır (Asadi vd., 2020: 8-9). Burada /t/ sesi ve alofonları ötümsüz olmasına rağmen yüksek damlacık oluşturması yönüyle ilgi çekicidir. Örneğin bir çalışmada İng. stay healthy "sağlıklı kal" ifadesindeki ötümsüz diş sızıcısı /-th-/ (IPA: / $\theta /$ ) sesinin örneklemde en fazla damlacık salınımına neden olan ses olduğu saptanmıştır (Anfinrud vd., 2020: 1-3). Bu bilgiler genel olarak ötümlü patlayıcıların ve burun ünsüzlerinin ${ }^{7}$ en yüksek damlacık yayılımına sahip ünsüzler olduğu, ötümsüz

\footnotetext{
6 Akciğerden büyük oranda engelsiz biçimde dışarı atılan damlacıklardaki viral yoğunluğun daha fazla olduğu düşünülmektedir (Wagner vd., 2017: 3460).

${ }^{7}$ Ünlülerin yanında burun ünsüzlerinin de damlacık yayılımında önemli bir rolü olduğu görülmektedir. Burun ünsüzleri tahliye edilen havanın bir kısmını burundan dışarıya atmakta, bu ünsüzler akustik açıdan bakıldığında burun yolunu kullanmaları dışında büyük oranda ünlülere benzemektedir. Türkiye Türkçesi ve ağızlarındaki burun ünsüzleri /m, n, y/ olup bu sesler, ünlülere göre daha düşük bir enerjiye sahiptir (Kılıç, 2018, s. 259). Bu açıdan bakıldığında ciğerden gelen havayı en az temasla dış ortama aktaran burun ünsüzleri, virüsün yayılmasında yüksek bir etkiye sahip olmakla birlikte, laboratuvar araştırmalarına da uygun olarak ünlülere kıyasla daha az tesirlidir. Kısacası akciğerlerden gelen havayı diğer ünsüzlere göre daha engelsiz bir biçimde tahliye eden burun ünsüzleri, etrafa ciğerlerdeki ve ses yolundaki enfeksiyonu
} 
sürtünmelilerin ise bu konuda yayılıma en az etki ettiği sonucuna varılmıştır (Asadi vd., 2020: 8-9). $\mathrm{Bu}$ durumda bu seslerin ünlülerle kurduğu fonetik birlikler, yüksek oranda damlacık barındırmaktadır.

Başta temel ünlüler olan /a, i, u/ olmak üzere ünlülerin ve /b, d, g, t/ ile burun ünsüzlerinin (/m, n, y/) yoğun bir damlacık üretim potansiyeline sahip olduğu düşünülürse ünlülerin düşük frekanslarda boğumlanmasının Türkçe konuşurlarına sağladığı avantajın, dilin genel kullanımında çok da işlerlikli olmadığı görülecektir. Bu Türkçenin ses birliklerinin yapısı ile alakalıdır. Nitekim Türkçenin ölçünlü dilinde gösterilen 29 ses içerisinde, damlacık yayma oranı yüksek olan aşağıdaki 9 sesin /g/ hariç tamamı, Türkçenin en çok kullanılan 15 sesinden biridir (bk. Karadağ, 2019: 15-16):

Tablo 3: Türkçedeki Damlacık Yayılımı Yoğun Seslerin Kullanılma Sıklığı

\begin{tabular}{lll}
\hline Ses & Oran & Sira \\
\hline $\mathrm{a}$ & $\% 12,1$ & 1. \\
\hline $\mathrm{i}$ & $\% 10,7$ & 2. \\
\hline $\mathrm{u}$ & $\% 2,9$ & 13. \\
\hline $\mathrm{b}$ & $\% 2,5$ & 15. \\
\hline $\mathrm{d}$ & $\% 4,1$ & 9. \\
\hline $\mathrm{g}$ & $\% 1,3$ & 20. \\
\hline $\mathrm{m}$ & $\% 3,7$ & 10. \\
\hline $\mathrm{n}$ & $\% 7,1$ & 4. \\
\hline $\mathrm{t}$ & $\% 3,1$ & 12. \\
\hline
\end{tabular}

Yine Türkçede en sık kullanılan üç ses, yoğun damlacık yayılımıyla bilinen ünlü fonemlerdir (Karadağ, 2019: 15-16). Nitekim bu, Türkçenin akıcılaşmaya yatkın, berrak ünlüleri tercih eden ve ünsüzlerden ziyade ünlü birleşimli hece yapılarını tercih eden bir dil olmasıyla açıklanabilir. Öyleyse Türkçenin boğumlanma esnasında düşük frekans değerleri üretmesinin salgın yönetimine yapacağ katkıya çok daha mesafeli yaklaşılmalıdır. Çünkü Türkçe ünlüler nazarında ne kadar düşük frekans değerleriyle boğumlanırsa boğumlansın Türkçede tercih edilen kelimelerdeki ses varlığının \%66'sını ünlüler ve /b, d, g, m, n, t/ ünsüzleri oluşturmaktadır (bk. Karadağ, 2019: 15-16). Bu da Türkçeİngilizce karşılaştırması bir kenara bırakılırsa Türkçe konuşma esnasında kullanılan seslerin yarıdan fazlasının virüs yayma potansiyeli yüksek fonemlerden oluştuğunu göstermektedir. $\mathrm{Bu}$ oran İngilizcede \%64,66 olup Türkçe ile oldukça yakındır (bk. Norvig, 2013, web). Bununla birlikte İngilizcede, damlacık yayılımı çok yüksek bir fonem olan/t/ ve bu sesin akıcılaşmış hâli olan /th/çok

yayma konusunda ünsüzler arasında ön plana çıkmaktadır. Hatta bu özellikleri nedeniyle ses yolundaki engellerle mümkün olduğunca çatışmadan ağız ve burun yolunda ilerleyen bu sesler, herhangi bir üst solunum yolu enfeksiyonunda, ünlülerle birlikte diğer fonemlere göre boğumlanma kalitesi açısından çok daha istikrarlıdır (Wagner vd., 2017: 3460). 
yüksek bir kullanım sıklığına sahiptir. Nitekim İngilizce konuşma esnasında neredeyse her 10 sesten biri /t/ $(\% 9,28)$ olup /th/ ise \%3,56 oranla en çok kullanılan ünsüz çiftidir (bk. Norvig, 2013, web).

Bulaşı meselesini doğrudan etkileyen bir diğer mevzu seslenme ve esenlik kelimelerinin durumudur. Damlacık yayılımının yüksek sesle konuşma esnasında daha yoğun olduğu düşünüldüğünde, insanların tanıdıkları bir kişiyi gördüklerinde ev dişı ortamların çoğunlukla gürültülü olması sebebiyle "merhaba, günaydın, iyi akşamlar" gibi ifadeleri yükssek sesle telaffuz etmesi, çocukların “anne, baba" gibi kelimeleri ünlemli bir biçimde söylemesi ve "gel, git, haydi, bak" gibi harekete geçirici kelimelerdeki yükselen frekans değerleri damlacık yayılımı hususunda yoğunlaştırıcı etki yapabilecek düzeydedir. Yukarıda verilen kısıtlı sayıdaki örneğe bakıldığında bile Türkçedeki bu tarz kelimelerde ünlülerin yanı sıra burun ünsüzleri veya patlayıcı ünsüzlerin ne denli yoğun bulunduğu görülmektedir.

\section{Sonuç}

Ünlülerin Türkçe konuşma esnasındaki damlacık yayılımının İngilizce ile karşılaştırılması sonucunda şu sonuçlara varılmıştır:

1. Türkçe konuşmalarda ünlüler, Amerikan İngilizcesiyle kıyaslandığında daha düşük frekans değerleri üretmektedir.

2. Amerikan veya Britanya İngilizcesini Türk aksanıyla konuşan bireylerin kullandıkları ünlüler, ana dillerini (Türkçeyi) konuşurken kullandıkları ünlülerden bir miktar daha yüksek frekanslara sahiptir.

3. Ünlüler hususunda İngilizceden daha düşük frekanslar üreten Türkçe bu yönüyle havanın dış ortama tahliyesi konusunda İngilizceye göre daha az basınca ihtiyaç duymaktadır. Bu durumun yayılan damlacıkların sayısına etkisi farazi olsa da, frekansın gücü nedeniyle İngilizce ünlülerin en azından damlacıkları daha geniş bir alana yayma kabiliyeti olduğu anlaşılmaktadır. Ancak bunun salgının boyutuna etki edecek derecede önemli bir fark doğurup doğurmayacağı açık değildir. Çünkü Türkçe konuşma esnasında kullanılan seslerin \%66'sı damlacık yayılımı yüksek fonemlerdir. Ayrıca Türkçedeki "merhaba, anne, baba, gel, git, haydi” gibi sıkça yüksek sesle kullanılan seslenme veya esenlik sözcüklerinin muhtevasında yüksek sesle boğumlanma esnasında yoğun damlacık yayılımı gösteren sesler bulunmaktadır. Bu açılardan bakıldığında konuşma damlacıkları vasıtasıyla pandemiyi yayma riskinin yalnızca dillerin ötümlülük-ötümsüzlük ve frekans dereceleri ile belirlenemeyeceği, bulaşı yoğunluğu açısından Türkçenin bariz bir şekilde İngilizceden daha az riskli bir dil olduğu kanısına varılamayacağı değerlendirilmektedir. 


\section{Kaynakça}

Aksan, D. (2015). Her yönüyle dil. Ankara: Türk Dil Kurumu.

Anfinrud, P., Stadnytskyi, V., Bax, C. E., \& Bax, A. (2020). Visualizing speech-generated oral fluid droplets with laser light scattering. New England Journal of Medicine.

Artuner, H. (1994). Bir Türkçe fonem kümeleme sistemi tasarımı ve gerçekleştirimi. Yayımlanmamış Doktora Tezi. Hacettepe Üniversitesi, Ankara.

Asadi, S., Wexler, A. S., Cappa, C. D., Barreda, S., Bouvier, N. M., \& Ristenpart, W. D. (2020). Effect of voicing and articulation manner on aerosol particle emission during human speech. PloS one, 1-15.

Boë, L. J., Heim, J. L., Abry, C., \& Badin, P. (2004). Neandertal vocal tract: Which potential for vowel acoustics?. Interaction Studies, 5(3), 409-429.

Boë, L. J., Heim, J. L., Honda, K., Maeda, S., Badin, P., \& Abry, C. (2007). The vocal tract of newborn humans and Neanderthals: Acoustic capabilities and consequences for the debate on the origin of language. A reply to Lieberman (2007a). Journal of Phonetics, 35(4), 564-581.

Çiyiltepe, M. \& Bekar, P. \& Ergenç, İ. (2009). Changing formant values: synthesis of four regions of Turkey. Turcologica 79. Wiesbaden: Otto Harrassowitz, 3-10.

Davutoğlu, A. Y. (2010). Standart Türkçedeki ünlülerin akustik analizi ve fonetik altyapı. Sanatta Yeterlilik Tezi, İstanbul Üniversitesi.

Ergin, M. (2005). Türk dil bilgisi. İstanbul: Bayrak.

Göksel, A., \& Kerslake, C. (2004). Turkish: A comprehensive grammar. Routledge.

Hunter, G., \& Yarkiner, Z. (2014). Formant frequencies of British English vowels produced by native speakers of Cypriot Turkish. Proceedings of the Institute of Acoustics, 36, 452-459.

Inouye, S. (2003). SARS transmission: language and droplet production. The Lancet, 362 (9378), 170.

Karadağ, Ö. (2020). Türkçe eğitimi açısından ses-harf sıklığı üzerine bir değerlendirme. Ana Dili Ĕ̈itimi Dergisi, 8 (1), 1-13.

Korkmaz, Y., \& Boyac1, A. (2018). Examining vowels' formant frequency shifts caused by preceding consonants for Turkish Language, Journal of Engineering and Technology, 2 (2), 38-47.

Korkmaz, Y., \& Boyacı, A. (2018). Classification of Turkish vowels based on formant frequencies. In 2018 International Conference on Artificial Intelligence and Data Processing (IDAP), 14. 
Kowalik, M. M., Trzonkowski, P., Łasińska-Kowara, M., Mital, A., Smiatacz, T., \& Jaguszewski, M. (2020). COVID-19- toward a comprehensive understanding of the disease. Cardiology Journal, 27 (2), 99-114.

Kılıç, M. A. (2018). Türkçedeki burun ünsüzlerinin akustik özellikleri. Turkish Studies, 13 (12), 259271.

Malkoç, E. (2009). Türkçe ünlü formant frekans değerleri ve bu değerlere dayalı ünlü dörtgeni. Dil Dergisi, (146), 71-85.

Morawska, L. (2005). Droplet fate in indoor environments, or can we prevent the spread of infection?. In Proceedings of Indoor Air 2005: the 10th International Conference on Indoor Air Quality and Climate, Springer, 9-23.

Ng, M. L., Chen, Y., \& Sadaka, J. (2008). Vowel features in Turkish accented English. International Journal of Speech-Language Pathology, 10 (6), 404-413.

Sadaka, J., \& Ng, M. (2006). Pronunciation of English vowels of native Turkish speakers. The Journal of the Acoustical Society of America, 119 (5), 3423-3423.

Saraç, E. T. (2010). Türkçe fonemlerin ünlü-ünsüz kombinasyonlarında nazalite değerlendirmesi. Yayımlanmamış Yüksek Lisans Tezi. Hacettepe Üniversitesi, Ankara.

Stadnytskyi, Valentyn \& Bax, Christina \& Bax, Adriaan \& Anfinrud, Philip. (2020). The airborne lifetime of small speech droplets and their potential importance in SARS-CoV-2 transmission. Proceedings of the National Academy of Sciences, 1, 3.

Wagner, J., Fraga-Silva, T., Josse, Y., Schiller, D., Seiderer, A., \& André, E. (2017). Infected Phonemes: How a Cold Impairs Speech on a Phonetic Level. In Interspeech, 3457-3461.

Wang, H., \& van Heuven, V. J. J. P. (2006). Acoustical analysis of English vowels produced by Chinese, Dutch and American speakers, Linguistics in the Netherlands, 23, John Benjamins, 237-248.

Wolff, M. H., Sattar, S. A., Adegbunrin, O., \& Tetro, J. (2005). Environmental survival and microbicide inactivation of coronaviruses. In Coronaviruses with special emphasis on first insights concerning SARS, Birkhäuser Basel, 201-212.

Varol, M. (2012). Influence of Turkish sound system on English pronunciation. Yayımlanmamış Yüksek Lisans Tezi. Florida State University. 